\title{
INOVASI ORGANISASI BISNIS: "BELAJAR DARI INOVASI HARIAN JOGJA DI TENGAH ARUS PERUBAHAN TEKNOLOGI”
}

\author{
Innovation of Business Organizations: “Learning From Harian Jogja Innovation \\ In The Middle of Flow of Changes In Technology"
}

Murdiyansyah H

Magister Ilmu Administrasi Fisip Uniska Banjarmasin

Yulisanus Alfonsi Madur

Instansi Dinas Pendidikan Kab. Manggarai NTT

\section{Sunardi}

Peneliti Muda di Law \& Democracy Institute

E-mail : cunacuna05@gmail.com

Naskah diterima tanggal 22 Juni 2018, Naskah direvisi 29 Oktober 2018, Naskah disetujui 1 November 2018

\begin{abstract}
Abstark
Tulisan ini akan mengeksplorasi temuan tentang inovasi yang dilakukan Harian Jogja untuk bisa bertahan ditengah gempuran teknologi, serta faktor yang mempengaruhi proses inovasi pada Harian Jogja. Menggunakan metode penelitian kaualitaf, hasilnya menunjukan bahwa Harian Jogja melakukan tiga inovasi untuk bisa bertahan, pertama Harian Jogja berinovasi pada desain cover, kedua Harian Jogja melakukan inovasi pada rubrik (konten), dan ketiga Harian Jogja berinovasi dengan menciptakan koran anti malaria. Keberhasilan inovasi Harian Jogja dipengaruhi oleh faktor budaya organisasi, teknis dan organisasi pembelajaran.
\end{abstract}

Kata Kunci: Inovasi; Organisasi Binis; Media Cetak

\section{Abstract}

This paper questioned the innovations by Harian Jogja in order to survive in the onslaught of technology advances. The research method in this paper is qualitative, and the result shows that Harian Jogja makes three innovations. First, innovation in the cover design, second, innovation in the content, and the third, they makes an innovation by created the anti malaria newspaper. The success of innovation in Harian Jogja was influenced by cultural factors of organization, technical and learning organization.

Keywords: The Innovation; Harian Jogja

\section{PENDAHULUAN}

$\mathrm{H}$ arian Jogja merupakan salah satu media massa yang lahir dari rahim reformasi. Merupakan media massa dengan terbitan berkala yang dicetak setiap hari. Berdiri sejak tahun 2008, Harian Jogja telah mendapat banyak perhatian publik. Ini terlihat dari indeks penyebaran harian Jogja yang meliputi hampir diseluruh kota/kabupaten yang ada di D.I Yogyakarta, seperti daerah Kulonprogo, Sleman, Jogja, Bantul, dan Gunungkidul.

Tabel. 1 Wilayah Penyebaran Harian Jogja

\begin{tabular}{|c|l|l|}
\hline No & Kabupaten/Kota & Jumlah (\%) \\
\hline 1 & Gunung Kidul & $19 \%$ \\
2 & Bantul & $15 \%$ \\
3 & Yogjakarta & $32 \%$ \\
4 & Sleman & $20 \%$ \\
5 & Kulonprogo & $9 \%$ \\
6 & Dll & $5 \%$ \\
\hline
\end{tabular}

Sumber : Profil Harian Jogja, 2016
Tetapi, hasil ini tidak menunjukan bahwa Harian Jogja, media cetak pada umumnya tidak mengahadapi masalah yang serius. Data yang dirilis oleh Nielsen Media Research pada tahun 2014 menunjukan kecenderungan konsumsi masyarakat terhadap Koran (media cetak) masih sangat rendah yaitu pada urutan ke-4 (12\%) setelah radio (20\%), internet (30\%) sementara yang paling tinggi adalah televisi dengan presentase $90 \%$. Hal ini selain karena minat baca yang mulai menurun juga disebabkan oleh selera konsumsi masyarakat terhadap media cetak yang telah bergeser ke media eletronik. Implikasinya, harian Jogja akan mengalami krisis pembaca ketika tidak merespon perubahaan budaya dan teknologi yang berkembang ditengah-tengah masyarakat. Berikut hasil penelitian Nielsen Media Research tentang pengguna media. 
Tabel.2

Pengguna Media Massa Tahun 2014

\begin{tabular}{|c|l|c|}
\hline No & Media Massa & Jumlah (\%) \\
\hline 1 & Televisi & $90 \%$ \\
2 & Internet & $33 \%$ \\
3 & Radio & $20 \%$ \\
4 & Koran & $12 \%$ \\
5 & Tabloid & $6 \%$ \\
6 & Majalah & $5 \%$ \\
\hline
\end{tabular}

Sumber: Diolah dari Situs Nielsen Media Research, 2015

Meskipun demikian, sejauh ini harian Jogja masih banyak diminati oleh masyarakat. Terbukti sejak berdiri tahun 2008 sampai saat ini harian Jogja telah meraih beberapa pengahargaan sebagai media favorit di antaranya Indonesia Premedia Award sebanyak 5 dari 6 kali penyelenggaraan sejak tahun 2009, sebagai media cetak di Jawa yang memiliki desain cover terbaik, dengan kategori The Best on Coverside. Sehingga pada kondisi seperti itu, penulis ingin mengetahui lebih jauh proses inovasi yang berlangsung pada harian Jogja.

Studi mengenai inovasi pada media massa sebenarnya belum terlalu banyak dilakukan, hanya beberapa diantaranya studi yang dilakukan oleh Candra (2016) dengan judul studi Komparasi Proses Inovasi (Proses Inovasi RRI Yogyakarta Dan Radio Suaragama). Fokus studi pada proses inovasi mulai dari pembangkit ide, mengubah ide dan penyebaran hasil inovasi. Hasilnya, terdapat persamaan dan perbedaaan pada proses inovasi dilihat dari segi strategi inovasi. Perbedaan tersebut disebabkan oleh lingkungan kerja dan kemampuan organisasi. Akibatnya Radio Swaragama lebih sering mengudara dibandingkan dengan RRI karena lingkungan kerja lebih menunjang untuk proses inovasi serta kemampuan organisasi yang hampir merata di seluruh lini. Kelemahan pada studi ini tidak melihat proses inovasi pada media cetak.

Selain itu, studi yang dilakukan oleh Kriska (2013) pada surat kabar lokal Daerah Istimewa Yogyakarta (DIY). Fokus studinya pada penyajian berita pertanian yang memuat informasi mengenai inovasi dalam bidang pertanian serta melakukan perbandingan isi/konten yang berkaitan dengan informasi inovasi pertanian. Hasilnya konten paling baik inovasinya adalah inovasi teknologi. Akibatnya semakin baik konten informasi yang disajikan proses inovasi pada pertanian juga akan semakin baik.
Tetapi kelemahan pada studi ini, hanya melihat hubungan konten informasi dengan inovasi pada pertanian tidak melihat aspek proses inovasi media cetak dengan kecenderungan pembaca.

Sementara itu, studi lain seperti Saputri (2011) dengan judul Analisis Inovasi Nilai Kedai Digital Yogyakarta, lebih fokus melihat proses inovasi pada kedai digital sebagai media informasi serta pada penciptaan nilai pada kedai digital dalam menghadapi persaingan bisnis. Akhirnya studi ini tidak sedikitpun menyinggung bagaimana inovasi pada media cetak sebagai penyalur informasi tetapi lebih kepada kedai digital. Lain halnya dengan Yulianarko (2013) pada studi di Sleman. Meskipun tidak memotret secara jauh proses inovasi pada media cetak, tetapi kontribusi yang diberikan pada studi ini adalah melihat proses inovasi pada konten pemberitaan terhadap perubahaan inovasi pada petani. Relevansi dengan media cetak adalah melihat hubungan antara proses inovasi khususnya pada konten dengan kebutuhan pelanggan. Tetapi studi ini masih terbatas karena hanya berlangsung pada Televisi. Sehingga masih terdapat celah bagi penelitian yang akan di lakukan (Lihat Tabel. 3).

Secara umum studi-studi sebelumnya mengenai inovasi media massa masih banyak bertumpu pada televisi dan radio. Masih kurang studi yang melakukan riset mengenai inovasi yang berlangsung pada media cetak, adapun beberapa yang melakukan seperti Kriska (2013) tetapi tidak melihat inovasi yang dikembangkan pada Koran tetapi lebih kepada hubungan konten informasi dengan inovasi pada masyarakat.

Sehingga yang menjadi kontribusi bagi riset ini adalah melihat bagaimana media cetak, Harian Jogja pada khususnya melakukan proses inovasi ditengahtengah perubahaan teknologi dan perubahaan struktur pasar (Globalisasi). Adapun yang menjadi rumusan masalah mini riset ini adalah:

1. Bagaimana proses inovasi yang berlangsung pada harian Jogja?

2. Faktor apa yang mempengaruhi proses inovasi pada harian Jogja? 
Tabel. 3

Penelitian Sebelumnya Mengenai Inovasi Pada Media

\begin{tabular}{|c|l|l|}
\hline No & \multicolumn{1}{|c|}{ Studi } & \multicolumn{1}{c|}{ Fokus } \\
\hline 1 & $\begin{array}{l}\text { Candra (2016), "Studi } \\
\text { komparasi proses ino- } \\
\text { vasi (Proses inovasi RRI } \\
\text { Yogyakarta dan Radio } \\
\text { Swaragama)". }\end{array}$ & $\begin{array}{l}\text { Komparasi Proses inovasi mulai } \\
\text { dari pembangkit ide, pengubah } \\
\text { ide dan penyebaran hasil ino- } \\
\text { vasi. }\end{array}$ \\
\hline 2 & $\begin{array}{l}\text { Saputri (2011), "Anali- } \\
\text { sis inovasi nilai di kedai } \\
\text { digital Yogyakarta }\end{array}$ & $\begin{array}{l}\text { Inovasi nilai yang diciptakan } \\
\text { oleh kedai digital serta faktor } \\
\text { yang mempengaruhinya }\end{array}$ \\
\hline 3 & $\begin{array}{l}\text { Kriska (2013), "kontri- } \\
\text { busi surat kabar lokal } \\
\text { DIY dalam penyebaran } \\
\text { informasi inovasi per- } \\
\text { taniain } \\
\text { Yulianarko(2013), }\end{array}$ & $\begin{array}{l}\text { Konten informasi (Penyajian } \\
\text { berita) } \\
\text { berita inovasi pertanian } \\
\text { pada media televisi di } \\
\text { Kecamatan Kalasan } \\
\text { Kabupaten Sleman }\end{array}$ \\
\hline 4
\end{tabular}

\section{METODE PENELITIAN}

Penelitian ini menggunakan pendekatan kualitatif, dengan model pengumpulan data berupa observasi dan wawancara langsung. Wawancara langsung dilakukan oleh pimpinan Harian Jogja dan beberapa karyawan yang terlibat serta mengetahui banyak tentang tema yang diteliti, sedangkan observasi langsung dilakukan dengan mengamati setiap proses yang berlangsung di kantor redaksi Harian Jogja.Termasuk dengan mengamati sekaligus menganalisis respon yang diberikan oleh pembaca dengan menganalisis hasil penjualan dan penyebaran Harian Jogja. Wilayah yang menjadi pengamatan artikel ini tersebar di beberapa titik, seperti Gunung Kidul, Bantul, Yogyakarta, Sleman, dan Kulonporogo dengan mengatami minat pembaca koran Harian Jogja pada daerah-daerah tersebut. Dimana data diperoleh dengan menggunakan data skunder berupa laporan rutin yang telah dihimpun oleh team Harian Jogja, yang kemudian mengambil sampel pembaca dengan memperhatikan profesi seperti keterwakilan dari TNI/POLRI, Swasta, Mahasiswa, Pensiunan serta ASB (Aparatur Sipil Negara). Aspek ini khususnya di maksudkan untuk mengetahui respon pembaca terhadap dengan Harian Jogja.

Selain itu, pengumpulan data juga dilakukan dengan melakukan survei kepada beberapa karyawan di Harian Jogja. Survei berlangsung selama tiga hari, dengan tujuan untuk mengetahui faktor dominan yang mempengaruhi inovasi yang terjadi di Harian Jogja.
Kemudian, hasilnya disajikan berupa data deskriptif, dengan penguatan hasil analisis berdasarkan dengan kerangka teori yang akan digunakan. Selanjutnya untuk hasil survei, digunakan sebagai alat ukur untuk mengetahui faktor manakah dari berikut ini yang paling berpengaruh environment composite, Learning Processes Composite \& leadership that reinforces learning, dengan terlebih dahulu mengkonversi hasil temuan survei ke dalam perhitungan Building Blocks and Their Subcomponentsdengan ketentuan scaled scoresbottom quatile (14-66), Second quartile (67-79), Median (7080), Third quartile (81-95) dan Top quartile (96-100).

\section{TINJAUAN PUSTAKA}

\section{Inovasi dalam Perdebatan Teori}

Ada banyak pendapat tentang inovasi. Diantaranya Vigoda-Gadot, dkk (2005). Kelompok ini berasumsi bahwa inovasi adalah sebuah proses yang diawali dengan penemuan idea tau memunculkan gagasan, selanjutnya ide dan gagasan yang masih bersifat abstrak di terjemahkan melalui suatu produk yang bersifat materi (nyata), hasil inilah yang kemudian didefinisikan sebagai inovasi (merujuk pada produk materi). Tetapi asumsi Vigoda-gadot dkk adalah proses inovasi yang terjadi pada sector publik.

Sementara Birkinshaw, dkk (2011) melihat proses inovasi pada perusahaan swasta. Asumsi yang dibangun bahwa inovasi adalah sesuatu yang dikerjakan secara kolektif dan kontinyu. Ini karena inovasi berkaitan dengan perubahaan ide (dinamika gagasan), perubahaan tersebut berdampak pada perubahaan transformasi nilai (value) dan layanan. Selain itu menurut Julian inovasi erat kaitannya dengan motivasi (dorongan internal) dan perubahaan teknologi. Sehingga inovasi tidak hanya di pahami sebagai proses yang stagnan, tetapi sebagai proses yang terus mengalami proses dialektika berdasarkan kondisi yang dihadapi.

Selain itu, Dyer, dkk (2009) lebih banyak menekankan proses inovasi pada individu.Asumsinya inovasi sangat dipengaruhi oleh DNA inovasi. Adapun DNA inovasi bisa berupa DNA genetika ataupun DNA yang terbentuk dari proses sosial (Rekayasa genetika). Sehingga pendapat ini melihat proses inovasi sebagai proses yang dimulai dari seorang individu yang selanjutnya terdistribusi pada yang lain. Implikasi untuk melihat proses inovasi yang harus lebih dulu di telesuri adalah kepribadian individu sebagai titik awal proses terbentuknya inovasi. Asumsi ini hampir selaras dengan pendapat Julian Birkinshaw, dkk (2011), hanya saja Dyer Jeffrey $\mathrm{H}$ lebih menekankan pada individu sementara Dyer (2009) menekankan pada kerja kolektif. 
Harian Jogja adalah perusahaan swasta, sehingga untuk melihat proses inovasi defenisi yang relevan untuk memotret fenomena inovasi tersebut adalah asumsi yang di kemukakan oleh Birkinshaw, dkk (2011) yaitu inovasi sebagai proses yang kolektif terdiri dari perubahaan ide (dinamika gagasan), transformasi nilai (value) dan layanan serta perubahaan teknologi. Selain karena fokusnya pada perusahaan swasta, juga relevan dengan penelitian yang akan dilakukan karena Julian menggunakan perubahaan sosial (budaya) dan intervensi teknologi sebagai variabel yang mempengaruhi proses inovasi. Tetapi di sisi lain asumsi Dyer, Jeffrey $\mathrm{H}$, dkk (2009) juga akan digunakan untuk melihat bagaimana awal proses inovasi yang berlangsung pada Harian Jogja. Adapun indikator yang digunakan untuk melihat DNA inovasi adalah inisiator, yaitu mengedintifikasi orang yang memulai ide atau gagasan tentang produk inovasi yang ada pada Harian Jogja.

\section{Faktor Yang Mempengaruhi Inovasi Pada Harian Jogja}

Seperti telah disebutkan sebelumnya bahwa inovasi pada Harian Jogja dapat di identifikasi dengan mengasumsikan inovasi sebagai proses yang kolektif (Birkinshaw, dkk, 2011). Sehingga untuk melihat faktor yang mempengaruhi proses inovasi akan lebih banyak ditekankan pada organisasi sebagai wadah bersama.

Salge \& Vera, (2012) meskipun tidak secara ekspleist menyebutkan faktor yang mempengaruhi inovasi pada media massa, tetapi pada studinya Salge setidaknya mengemukakan bahwa proses inovasi yang berlangsung di pengaruhi oleh beberapa kondisi seperti tuntutan masyarakat (Oriented Pelanggan), Orientasi belajar yang tinggi serta organisasi pembelajaran. Implikasinya inovasi tidak akan berlangsung dengan baik ketika ketiga kondisi ini terabaikan.

Selain itu David s. Pottruck $(2001 ; 119)$ melihat bahwa budaya perusahaan merupakan faktor yang dapat mendorong inovasi pada perusahaan, lebih jauh David mengemukakan ada tiga muatan budaya perusahaan yang dapat mempengaruhi inovasi, tiga point tersebut yaitu pertama menyangkut soal arah, permanen dan identitas. Kedua soal dorongan untuk inovasi dan terakhir menekankan peran aktif. Penekanan yang ingin di sampaikan oleh David bahwa budaya perusahaan memiliki nilai yang dijunjung tinggi dan sangat diyakini oleh perusahaan, sehingga inovasi dapat beruapa aktualisasi dari nilai-nilai yang terdapat pada perusahaan. Adapun kerangka teori yang digunakan pada penelitian ini adalah:

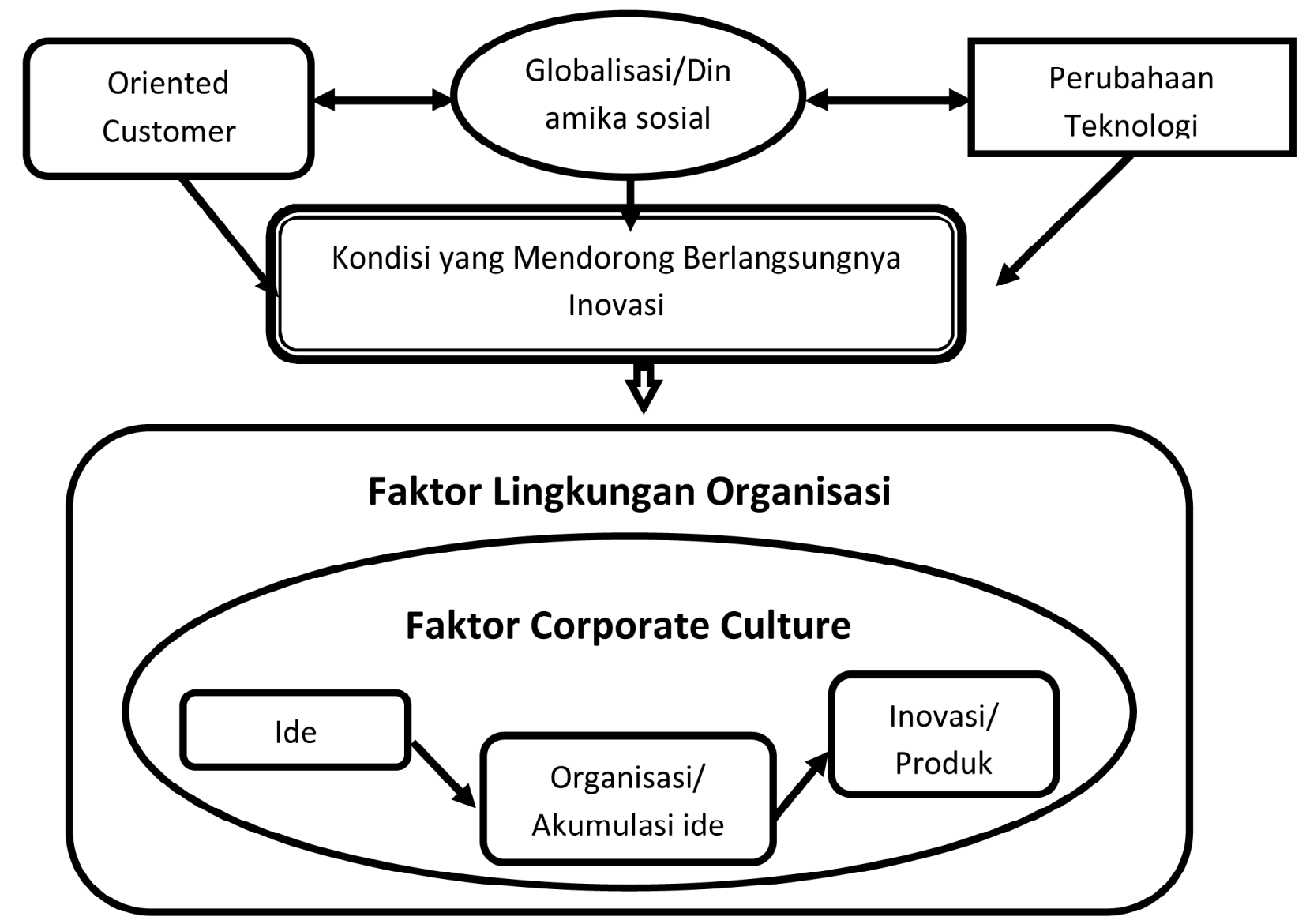

122 | Jurnal “Administrasi Publik” Volume XIV Nomor 2 Desember 2018 
Sementara studi lain seperti Kanter (2001:73) meskipun berbicara tentang budaya inovasi tetapi penekanannya lebih banyak kepada kalaeideskop seorang pemimpin. Asumsi yang ingin di bangun bahwa budaya inovasi sangat dipengaruhi oleh seorang pemimpin melalui kalaeideskopnya. Selaras dengan Jaskyte (2011) yang juga mengemukakan faktor yang menentukan proses inovasi diantaranya adalah pemimpin yang transformatif.

Berdasarkan uraian teoritis diatas, maka yang relevan dengan faktor yang akan mempengaruhi proses inovasi pada Harian Jogja adalah organisasi pembelajaran/orientasi belajar (Salge, dkk 2012) yaitu dengan menggunakan survey David A. Garvin, dkk (2008) untuk mengetahui sejauh mana organisasi pembelajaran pada Harian Jogja dengan melakukan pengukuran pada lingkungan belajar, kedua proses belajar, serta terakhir penguatan pada perilaku kepemimpinan. Sedangkan budaya perusahaan (David s. Pottruck (2001:119) yaitu menyangkut soal arah, permanen dan indetitas. kedua soal dorongan untuk inovasi dan terakhir menekankan peran aktif. Pemilihan variabel faktor diatas karena Harian Jogja merupakan perusahaan yang sangat mengedepankan budaya sebagai motivasi untuk bekerja, sesuai dengan slogannya "Berbudaya Membangun Kemandirian" (Baca, Profil harian Jogja).

\section{Inovasi Media Cetak}

Berdiri sejak tanggal 20 Mei 2008, Harian Jogja merupakan satu diantara sekian banyak media terbitan daerah yang ada di Yogyakarta. Dikelola oleh PT Aksara Dinamika Jogja (ADJ) di bawah payung bisnis Indonesia Group (BIG). Harian Jogja merupakan terbitan yang banyak diminati oleh masyarakat khususnya kalangan menengah, selain karena dikelolah oleh tenaga professional, harian Jogja di kenal dengan media yang mengedepankan kebutuhan informasi bagi kelas menengah. Hal itu bisa dilihat dari profil pembaca harian Jogja yang didominasi oleh kalangan swasta.

Tabel. 4

\section{Profil PembacaHarian Jogja}

\begin{tabular}{|c|l|c|}
\hline No & \multicolumn{1}{|c|}{ Profesi } & Jumlah (\%) \\
\hline 1 & TNI/POLRI & $1 \%$ \\
2 & Swasta & $30 \%$ \\
3 & Wir aswasta & $24 \%$ \\
4 & Pelajar/Mahasiswa & $7 \%$ \\
5 & Pensiunan & $7 \%$ \\
6 & ASN & $16 \%$ \\
7 & Lainnya & $15 \%$ \\
\hline
\end{tabular}

Sumber: Profil Harian Jogja
Selain itu, Anton W Prihartono selaku pemimpin redaksi Harian Jogja juga membenarkan bahwa harian Jogja merupakan media terbitan yang menggarap kelas menengah dan pelaku bisnis sebagai obyek pemasaran $^{1}$. Tidak mengejutkan ketika fakta menunjukan bahwa pembaca setia Harian Jogja lebih banyak diminati oleh kalangan swasta (30\%) serta wiraswasta $(24 \%)$

\section{Pendobrak Inovasi pada Harian Jogja}

Inovasi pada Harian Jogja berlangsung di tiga segmen. Pertama, inovasi menyisir area konten. Pada bagian ini lebih menekankan inovasi isi berita yang di sajikan. Untuk konten berita, Harian Jogja memilih informasi bisnis \& ekonomi sebagai berita yang di unggulkan. Inovasi konten bertujuan untuk memastikan segmen customer dari pembaca Harian Jogja tetap terjaga yaitu kelas menengah dan pelaku bisnis.

Kedua, inovasi berlangsung pada desain Harian Jogja. Pada bagian ini inovasi lebih mementingkan tampilan sebagai bagian dari strategi marketing Harian Jogja, seperti pada peremajaan tampilan yang menyajikan desain gambar serta fitur yang dipercaya dapat menggugah pembaca. Tujuan inovasi desain untuk menarik simpatisan pembaca pemula. Harapannya, tampilan awal akan memberikan daya tarik tersendiri sebelum pembaca lebih jauh menelusuri setiap informasi yang tersaji pada Harian Jogja. Harapannya, dengan inovasi desain mampu mengikat pembaca pada pandangan pertama sehingga pembaca untuk Harian Jogja akan terus bermunculan ditengah-tengah masyarakat.

Ketiga, Harian Jogja merupakan media cetak yang tidak hanya mementingkan konten berita serta keuntungan sebagai tujuan akhirnya. Melalui inovasi koran anti malaria, Harian Jogja sebagai media cetak bertransformasi menjadi penyelamat bagi masyarakat dari ancaman dengan menciptakan koran pencegah malaria. Inovasi ketiga ini di pilih karena situasi yang meresahkan akibat menyebarkan ancaman malaria khususnya di wilayah Yogjakarta. Tujuan inovasi ini, selain memberikan kebutuhan informasi khususnya di bidang ekonomi juga di maksudkan untuk memberi rasa aman bagi pembaca dengan perlindungan dari koran anti malaria sebagai terobosan dari Harian Jogja.

Ketiga inovasi yang terjadi pada Harian Jogja merupakan bentuk akhir dari akumulasi ide yang terus dikembangkan oleh Pak Anton beserta jajaran di Harian Jogja. Mengingat bahwa keberadaan media cetak ditengah gempuran teknologi dan perubahaan globalisasi menjadi satu ancaman yang sangat serius. Keberadaan teknologi tentu dapat mempermudah 
media cetak dalam hal ini Harian Jogja seperti kerja reportase di lapangan, tetapi pada aspek yang lain teknologi juga bisa menjelma sebagai ancaman dalam persaingan bisnis bagi Harian Jogja, misalnya pada persebaran informasi yang lebih praktis, cepat dan efisien baik oleh biaya maupun oleh tempat. Dengan situasi seperti ini, menjadi ancaman terbesae bagi Harian Jogja untuk di tinggalkan oleh pembacanya. Sehingga untuk tetap konsisten sebagai media cetak yang mengedepankan informasi di bidang ekonomi dan bisnis, perubahaan globalisasi serta arus teknologi justru menjadi satu pendobrak bagi segenap jajaran di redaksi Harian Jogja untuk melakukan inovasi, sebagaimana dikutip pada hasil wawancara berikut ini:

"Tantantangan yang di hadapi oleh media cetak seperti Harian Jogja adalah perubahan globalisasi dan arus teknologi. Disatu sisi, perubahan tersebut mempermudah kerja temanteman di lapangan seperti dalam menghimpun dan mengumpulkan berita, tetapi sekaligus menjadi ancaman. Sebab bukan tidak mungkin, keberadaan teknologi bisa mengancam keberlanjutan bisnis dari media cetak seperti Harian Jogja. Mengingat perubahan teknologi akan menggeser selera publik dari media cetak ke berita online." 2

Perubahan globalisasi yang berimbas pada arus teknologi juga berimplikasi pada semakin kompleksnya persaingan bisnis di media cetak seperti Harian Jogja. Persaingan bisnis di bidang pemberitaan yang terjadi meliputi persaingan antara sesama media, baik yang terjadi antara media cetak dengan media elektronik lainnya seperti televisi, radio, dan media online.
Selain itu, perubahaan teknologi juga merembes pada persaingan antara sesama media cetak baik yang terjadi di skala nasional maupun di skala lokal. Untuk Harian Jogja, persaingan nampak pada media cetak lokal lainnya seperti Tribun Jogja dan kedaulatan rakyat yang terus menggenjot penjualan dengan aktif melakukan inovasi. Sehingga kondisi persaingan bisnis yang terjadi membuat Harian Jogja tidak memiliki pilihan lain untuk tetap mempertahankan usaha sebagai penjual berita dengan ikut andil pada perubahan yang terjadi salah satunya melakukan inovasi atas dorongan dari penyesuaian terhadap persaingan bisnis yang ada.

Namun, terlepas dari dua dorongan diatas antara perubahan globalisasi dan arus teknologi serta persaingan bisnis, dorongan dari customer (pembaca) juga menjadi salah satu alasan yang menggerakan Harian Jogja intens melakukan inovasi diberbagai segmen. Dorongan ini sebagai bentuk reaksi dari pembaca yang ditunjukan secara tidak langsung. Grafik penjualan yang mengalami fluktuasi menjadi titik berangkat inovasi yang berlangsung pada Harian Jogja. Meskipun pada kondisi yang lebih konkret keterlibatan pembaca tidak secara langsung dikomunikasikan tetapi out put dari hasil kinerja penjualan sebagai indikasi keterlibatan customer sebagai pendobrak inovasi yang menggerakkan Harian Jogja melakukan inovasi baik berupa kemasan konten maupun desain. Faktanya, desakan customer yang direspon secara positive mampu mengembalikan segmen pasar Harian Jogja sebagai media unggulan dalam memberikan informasi seputar ekonomi dan bisnis di Daerah Istimewa Yogyakarta.

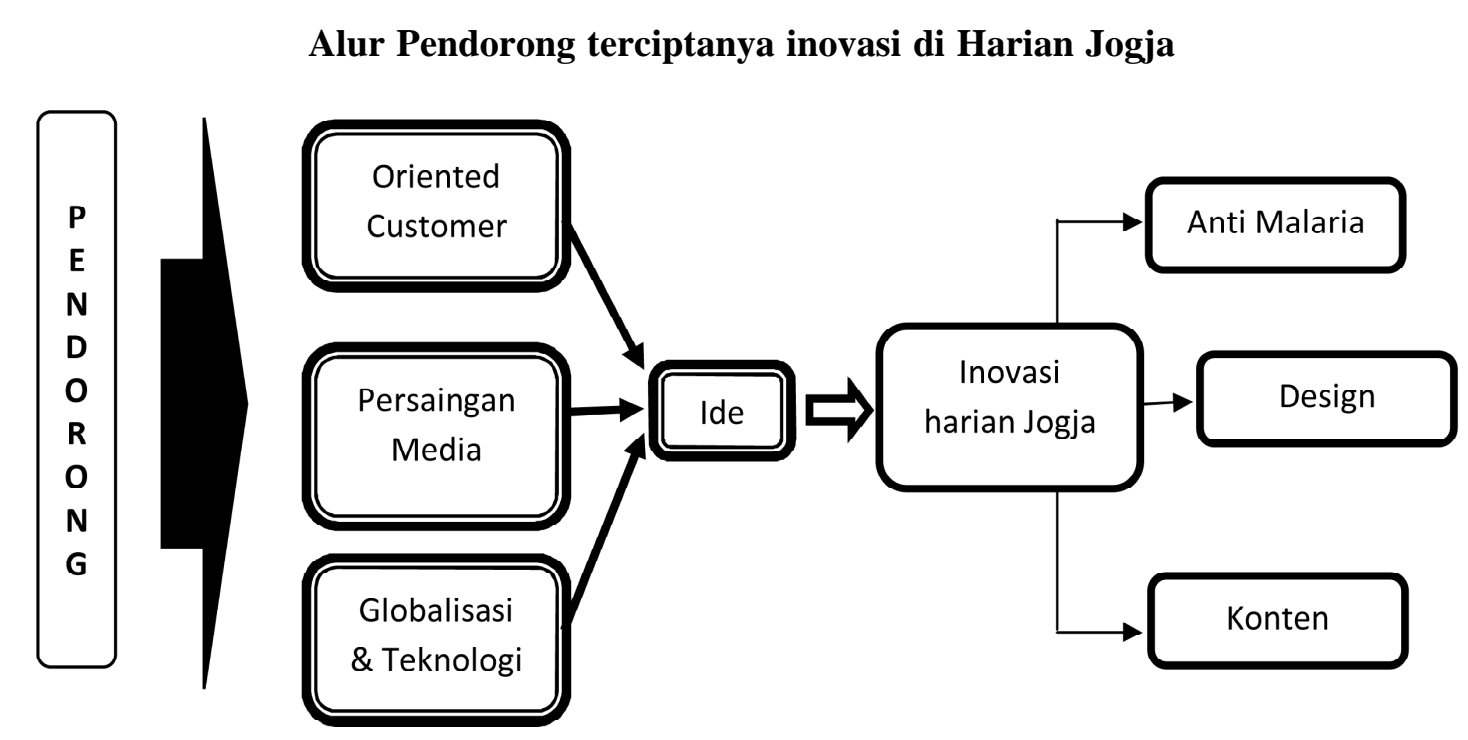

Sumber: Diolah dari hasil observasi \&wawancara 
"Inovasi yang berlangsung pada Harian Jogja, selain karena adanya dampak globalisasi dan arus informasi yang begitu cepat, juga di picu oleh dorongan dari customer. Mengingat Harian Jogja sangat mengedepankan penyajian informasi yang cepat. Hal ini jika tidak dilakukan, ancaman akan ditinggalkan oleh customer sangat mungkin terjadi. Karena itu, sebagai antisipasi yang dilakukan Harian Jogja terus melakukan perbaikan. Termasuk untuk hal perbaikan konten dan tampilan." 3

Skema diatas menunjukan bahwa inovasi pada harian Jogja diawali dari proses penciptaan ide. Adapun ide terbentuk banyak disebabkan oleh perubahaan global dan teknologi, adanya persaingan, serta oriented customer. Selanjutnya, ide akan diakumulasi, hasilnya berupa inovasi (produk), berupa koran anti malaria, desain dan konten.

\section{Proses Terciptanya Inovasi}

Inovasi yang berlangsung pada Harian Jogja seperti koran anti nyamuk, desain dan konten merupakan suatu rangkaian proses yang sangat panjang. Pada Harian Jogja, proses inovasi melalui dua tahapan, yaitu tahapan uji coba dan tahapan adopsi ide. Tahapan uji cobarupakan rangkaian dari proses inovasi yang mengesktrak ide yang telah terakumulasi menjadi satu produk inovasi. Proses ini diawali dengan mengkombinasikan hal baru pada model produksi sebelumnya. Pada Harian Jogja, proses uji coba berlangsung dengan mencampurkan cairan tertentu kedalam larutan tinta yang akan digunakan untuk mencetak koran Harian Jogja.

Pertama proses uji coba, memiliki tantangan tersendiri bagi perusahan sekelas Harian Jogja. Disisi lain, efisien dan efektiftas produksi selalu menjadi hal yang harus di utamakan, tetapi pada aspek yang lain proses inovasi harus merombak tatanan yang baru termasuk pada pola produksi lama. Sehingga proses uji coba yang terjadi di Harian Jogja maupun pada perusahaan lain selalu di jadikan sebagai momok yang mematikan, padahal pada tataran yang lebih konkreat, sebuah inovasi selalu berawal dari proses kesalahan dan uji coba yang tiada henti meskipun pada akhirnya akan menuai kegagalan. Begitupun dengan proses uji coba yang berlangsung di Harian Jogja, kesalahan demi kesalahan terus di hadapi, namun seiring dengan waktu mampu teratasi dengan baik hingga akhirnya terciptalah inovasi koran anti malaria.

"Semua proses inovasi yang berlangsung pada Harian Jogja merupakan eksperimen awal dari wujud sebuah ide. Semua di awali dengan coba-coba. Seperti pada proses inovasi untuk koran anti-Malaria. Awalnya cuma coba-coba mencampurkan zat tertentu pada tinta koran yang nanti digunakan pada saat percetakan. Dan akhirnya, secara mengejutkan sangat luar biasa. Meskipun dalam perkembangan proses ini masih mengalami kendala. Seperti pada mesin yang tidak menunjang. Tetapi untuk proses semua inovasi, semua berlangsung dengan coba-coba"4.

\section{Proses terciptanya inovasi pada Harian Jogja}

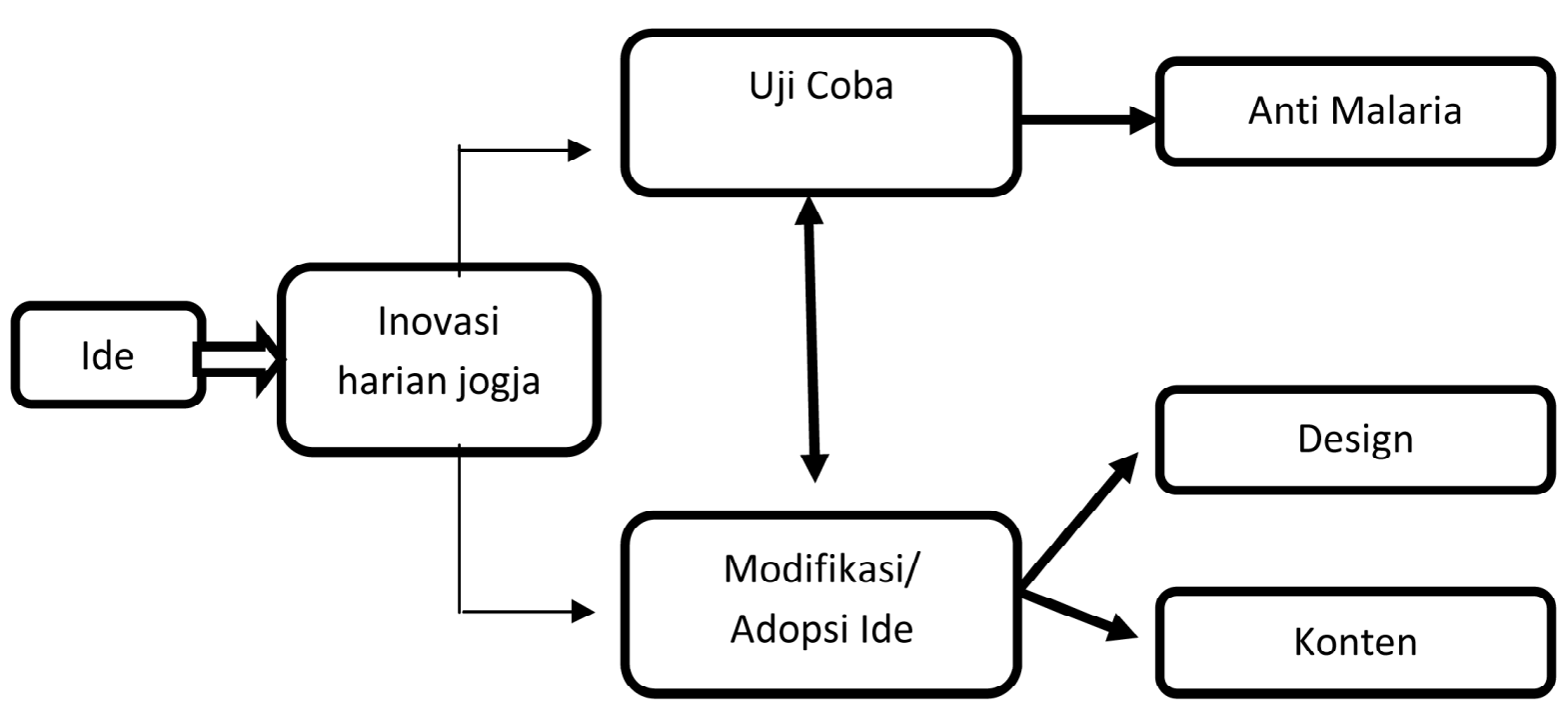


Kedua, proses inovasi berlangsung dengan melakukan adopsi ide dan modifikasi ide. Adopsi ini dilakukan dengan menerapkan sebagian inovasi yang terjadi pada media lain yang kemudian diterapkan pada Harian Jogja. Untuk adopsi ide, Harian Jogja lebih banyak mengadopsi ide-ide dari majalah berstandar internasional, seperti dari California.

"Tidak banyak yang mengetahui jika awalnya ide membuat inovasi desain pada Harian Jogja terinspirasi dari sebuah majalah dari California. Saat itu saya secara tidak sengaja membuka-buka media cetak semacam majalah dari California. Di sana saya terkesan dengan tampilannya yang sungguh menggugah saya itu membaca majalah tersebut. Ada daya tarik tersendiri. Sejak itu, saya mulai menerapkannya juga pada Harian Jogja dengan inovasi pada desain." 5

Desain sebagai salah satu segmen yang selalu di adopsi oleh Harian Jogja. Selain itu, Harian Jogja juga melakukan modifikasi ide. Dengan modifikasi ide, Harian Jogja punya ruang lebih besar untuk berkerasi. Modifikasi ide yang selalu di praktekan oleh Harian Jogja mengacu pada refrensi berupa buku yang selalu di sediakan oleh pimpinan redaksi untuk bagian desain.

\section{Varian Inovasi Pada Harian Jogja}

\section{a. Inovasi Konten}

Seperti disinggung sebelumnya, Harian Jogja merupakan media terbitan berkala dengan mengedepankan kelas menengah (pelaku bisnis) sebagai segmen pasarnya. Sehingga inovasi yang di lakukan khususnya pada konten lebih banyak pada rubrik ekonomi \& bisnis. Tujuannya menciptakan karakter Harian Jogja sebagai kiblat dari pelaku bisnis dengan menyediakan informasi seputar bisnis di sekitar Yogjakarta, misalnya informasi tentang proverti

"Salah satu kekuatan pada Harian Jogja terletak pada bagian koran yang menyediakan informasi tentang proverti. Bagian ini selalu dinantikan oleh pembaca. Ini sekaligus menjadi ciri khas sendiri dari Haria Jogja. Untuk iformasi proverti biasa diangkat pada hari Sabtu atau Minggu."

Inovasi konten Harian Jogja dilakukan dengan memberikan variatif informasi pada setiap edisi cetak, khususnya pada rubrik bisnis dan ekonomi mulai dari hari senin sampai minggu. Misalnya, untuk hari senin rubrik/konten pada Harian Jogja lebih banyak bertumpu pada berita tentang keuangan, alasannya konten ini di pilih untuk memberikan Informasi kepada pembaca terkait keuangan di awal pekan. Sementara di Hari selasa, konten proverty sebagai berita yang akan terjadi menghiasi terbitan Harian Jogja. Keberadaan konten properti untuk memastikan informasi penyebaran bisnis properti yang terjadi di sekitar wilayah Yogjakarta. Untuk hari rabu, konten berita Harian Jogja menyajikan informasi terkait perkembangan industri otomotif. Hari kamis menjadi hari spesial bagi warga Tionghoa, karena di hari ini Harian Jogja menyajikan berita seputar informasi tentang Tionghoa (Cina), Hari Jum'at menyajikan informasi terkait kuliner dan berbagai iformasi industri makanan, hari Sabtu mendorong ekonomi kreatif dengan menyajikan berita-berita inspiratif di bidang ekonomi, serta hari Minggu dengan segmen bisnis pemuda berisi berbagai informai tentang peluang usaha bagi kaum muda (Lihat Tabel. 5)

Tabel. 5 Inovasi konten pada Harian Jogja

\begin{tabular}{|c|c|c|}
\hline Hari & Konten & Tujuan \\
\hline Senin & Keuangan & $\begin{array}{l}\text { Mememberikan informasi ter- } \\
\text { kait jasa keuangan }\end{array}$ \\
\hline Selasa & Proverty & $\begin{array}{l}\text { Memberikan informasi ten- } \\
\text { tang proverty }\end{array}$ \\
\hline Rabu & Otomotif & $\begin{array}{l}\text { Memberikan informasi } \\
\text { tentang in dustry otomotif }\end{array}$ \\
\hline Kamis & Yu Hou & $\begin{array}{l}\text { Informasi seputar Tionghoa } \\
\text { (Cin a) }\end{array}$ \\
\hline Jumat & Hotel \& Resto & $\begin{array}{l}\text { Informasi tentang hotel dan } \\
\text { tempat makan }\end{array}$ \\
\hline Sabtu & Ekonomi Kreative & $\begin{array}{l}\text { Memberikan informasi ten- } \\
\text { tang ekonomi creative }\end{array}$ \\
\hline Minggu & $\begin{array}{l}\text { Diantaranya "The } \\
\text { Young" }\end{array}$ & Segmen un tuk anak Remaja \\
\hline
\end{tabular}

Sumber: Diolah dari hasil wawancara, 2016.

Alasan pasar, sebagai pendorong inovasi berbagi konten yang dilakukan oleh Harian Jogja. Dengan bertumpu pada pelaku ekonomi khususnya untuk pelaku ekonomi di masyarakat kelas menengah. Sehingga tidak ada pilihan yang lain bagi Harian Jogja untuk terus mempertahankan pembaca setianya dengan menyajikan konten atau informasi yang menunjang kegiatan bisnis bagi masyarakat menengah yang ada di Yogjakarta.

Selain itu, harian Jogja merupakan salah satu media terbitan yang menjadikan usia remaja sebagai target pemasaran. Pada segmen tersebut, inovasi yang dilakukan harian Jogja dikenal dengan sebutan "The Young" yaitu sebuah inovasi pada konten informasi yang lebih mengedepankan semangat dari remaja. Seperti informasi tentang tempat nokrong.

"The Young itu menjadi segmennya anak muda. The Young secara khusus menyediakan ruang bagi informasi untuk anak muda. Kami 
merasa, potensi pembaca yang juga cukup besar adalah pelajar dan mahasiswa. Karena itu berita yang disajikan setidaknya ada yang bisa mewakili karakter mereka."

Tabel. 6

Klaster Usia Pembaca Harian Jogja

\begin{tabular}{|c|c|c|}
\hline No & Usia & Presentase \\
\hline 1 & $<20$ Tahun & $6 \%$ \\
2 & $21-30$ Tahun & $13 \%$ \\
3 & $31-40$ Tahun & $35 \%$ \\
4 & 42-50 Tahun & $25 \%$ \\
5 & $>51$ Tahun & $21 \%$ \\
\hline
\end{tabular}

Sumber: Profil Harian Jogja

Inovasi The Young pada Harian Jogja berkontribusi besar terhadap minat pembaca khususnya pada dunia remaja. Hal tersebut tergambarkan pada grafik berikut yang menunjukan presentase pembaca harian Jogja dilihat dari umurnya, $35 \%$ pembaca Harian Jogja berusia 31-40 Tahun (Lihat Tabel. 6)

Pada aspek yang lain, juga terdapat inovasi pada konten informasi di Harian Jogja berupa rubrik bahasa daerah. Pada rubrik ini, informasi yang disampaikan menggunakan bahasa Jawa. Ini dilakukan sebagai salah satu wujud dari komitmen harian Jogja sebagai media lokal yang menjunjung nilai budaya. ${ }^{8}$ Keseriusan Harian Jogja menjadikan budaya lokal sebagai acuaninovasi bertahan ditengah-tengah kompleksitas budaya sebagai wujud dari pengamalan slogan Harian Jogja yang mengusung Berbudaya Membangun Kemandirian. Inovasi konten berbahasa daerah khususnya pada edisi cetak setiap hari Sabtu,

Salah satu dampak dari adanya rubrik yang berbahasa daerah berimplikasi pada penyebaran Harian Jogja yang tidak hanya tertuju pada satu kota tetapi hampir diseluruh daerah meliputi Sleman, Bantul, Gunung Kidul, Kulonprogo, Klaten dan Magelang. Menariknya, sekalipun Harian Jogja menargetkan kelas menengah dan pelaku bisnis sebagai target pembacanya, tetapi pada edisi tertentu seperti di hari Sabtu Harian Jogja juga masih menyisir masyarakat tradisional dengan konten berita yang berbahasa daerah. Berbeda dengan media cetak lainnya, Harian Jogja selalu komitmen menjaga nilai lokalitas seperti Bahasa daerah sebagai warisan leluhur yang terus di jaga salah satunya dengan menjadikan bahsa daerah sebagai bahasa pengantar pada edisi cetak koran Harian Jogja. Alasan ini juga yang kemudian membuat eksistensi Harian Jogja di daerah pelosok terus terjaga dengan baik.
Tabel. 7

Inovasi Pada Harian Jogja

\begin{tabular}{|l|l|l|}
\hline $\begin{array}{l}\text { Inovasi } \\
\text { Konten }\end{array}$ & \multicolumn{1}{|c|}{ Inovasi } & \multicolumn{1}{|c|}{ Target Pembaca } \\
\hline $\begin{array}{l}\text { Ekonomi } \\
\text { \& Bisnis }\end{array}$ & $\begin{array}{l}\text { Menyajikan informasi vari- } \\
\text { atif terkait dengan perkem- } \\
\text { bangan bisnis } \\
\text { Young } \\
\text { Menyajikan informasi terkait } \\
\text { perkembangan remaja saat } \\
\text { ini, seperti tempat nokrong }\end{array}$ & Pelaku bisnis \\
Bahasa & $\begin{array}{l}\text { Menyajikan informasi de- } \\
\text { nan menggunakan bahasa } \\
\text { daerah }\end{array}$ & $\begin{array}{l}\text { Daerah Sleman, Bantul, Gu- } \\
\text { nungkidul, Kulonprogo, Klaten } \\
\text { dan Magelang. }\end{array}$ \\
\hline
\end{tabular}

Sumber: Data Lapangan, 2016

\section{b. Inovasi Desain}

Inovasi desain pada Harian Jogja dilakukan untuk menselaraskan antara konten dengan tampilan. Ini dilakukan untuk memberikan kesan pertama yang lebih atraktif dengan penyampaian visualisasi melalui desain. Konten berita pada sebuah koran seperti pada Harian Jogja sangat penting, terlebih ketika Harian Jogja ingin menjaga substansi dari setiap konten yang di sajikan. Namun, menjadi kendala ketika konten yang tersaji dengan substansi berita yang berkualitas tidak di topang oleh tampilan yang memanjakan. Belum lagi, bagi pembaca pemula konten atau isi berita menjadi urusan kesekian yang lebih di utamakan adalah daya tarik berupa tampilan dan desain.

Atas dasar itu, untuk bisa bertahan ditengah gempuran teknologi Harian Jogja selain perlu mempertimbangkan konten berita yang di sajikan juga mesti memikirkan desain sebagai busana atas setiap ide pada Harian Jogja.

Salah satu inovasi yang terjadi pada Desain Harian Jogja dilakukan pada bagian cover koran. Inovasi ini dimaksudkan untuk memberikan kesan pertama terhadap pembaca. Dalam perkembangannya cover desainakan berubah mengikuti dinamika dan perkembangan yang terjadi. Hal ini dilakukan untuk mengikuti perkembangan tren khususnya yang menjadi isu perbincangan baik dimedia sosial maupun media cetak lainnya. ${ }^{9}$ Adapun kewenangan untuk cover desain menjadi kewenangan penuh untuk team creative yang memiliki keleluasaan untuk menciptakan desain yang lebih antraktir.

Akhirnya, bagian ini menjelaskan bahwa inovasi yang terjadi pada harian Jogja bukan hanya terfokus pada konten tetapi untuk menjawab tantangan dan dinamikan perkembangan masyarakat desain cover juga menjadi fokus inovasi yang perlu diperhatikan.

\section{c. Koran Anti Malaria}

Koran anti nyamuk adalah salah satu inovasi Harian Jogja. Inovasi koran anti malaria menggunakan 
cairan tertentu pada lembaran koran sehingga nyamuk tidak bisa mendekat. Inovasi ini memberikan kenyamanan pada pembaca yang dapat membaca tanpa terganggu dengan gangguan nyamuk atau serangga lainnya. Dengan inovasi "koran anti malaria" Harian Jogja semakin diminati oleh pembacanya.

Koran anti Malaria lahir dari suatu keadaan darurat malaria yang melanda Daerah Istimewa Yogjakarta. Peristiwa darurat malaria ini terjadi sekitar tahun 2014 hingga paruh waktu 2015, yang berakibat pada tingginya korban berjatuhan seperti demam berdarah. Namun, oleh pak Anton bersama dengan crew Harian Jogja yang lainnya tidak serta merta menjadikan bencana ini sebagai penghambat untuk berkreasi. Justru dengan tingginya angka demam berdarah yang menlanda Yogjakarta akibat dari malaria menjadi cikal bakal bagi Harian Jogja untuk mengembangkan sebuah inovasi yang diberi sebutan koran anti malaria. ${ }^{10}$

Inovasi koran anti malaria saat itu dipercaya sebagai inovasi pertama pada media cetak yang mengusungkoran yang mencegah serangga termasuk malaria. Koran anti malaria bekerja seperti layaknya pengusir serangga, aroma yang melekat pada setiap lembaran menjadikan serangga tidak betah pada radius tertentu. ${ }^{11}$ Sementara untuk menciptakan koran anti malaria, Harian Jogja hanya memberikan cairan tertentu yang kemudian di campurkan dengan tinta yang akan digunakan sebagai digital print pada percetakan Harian Jogja.

Meskipun koran anti malaria di klaim sebagi inovasi termurakhir di media cetak, bukan tidak mungkin pada proses penciptaannya inovasi ini berjalan dengan baik. Berbagai tantang turut menghantui inovasi koran anti malaria Harian Jogja. Salah satunya yang terekam dalam penelitian adalah kendala teknis seperti mesin produksi. Inovasi berupa koran anti malaria tidak dibarengi dengan inovasi di sektor teknologi produksi, sehingga berimbas pada penggunaan mesin operasional yang sedkit terhambat.Hal ini sampai berdampak pada produksi koran anti malaria yang sempat terhenti setalah tiga bulan produksi, alasan pemberhentian karena mesin yang digunakan untuk produksi belum familiar dengan bahan baku baru berupan cairan yang di larutkan bersamaan dengan tinta cetak Harian Jogja.

Ini menunjukan bahwa inovasi pada Harian Jogja tidak semuanya bisa berjalan dengan baik. Ada kondisi dimana inovasi tersebut harus dihentikan. Tetapi, bukan berarti bahwa inovasi ini gagal. Justru pengalaman inilah yang menjadi pengetahuan baru (ide baru), selanjutnya dikembangkan menjadi inovasi yang lebih kekinian. Senada dengan hal tersebut, Anton pada wawancara mengatakan:
Sehingga, untuk inovasi Koran anti malaria belum bisa dikatakan sebagai produk yang gagal tetapi lebih tepatnya proses penyesuaian dengan keadaan yang ada mulai dari sumberdaya sampai kepada persoalan teknis. Sekaligus menjelaskan bahwa proses inovasi bukanlah sesuatu yang stagnan tetapi terus bergerak.

Tabel. 8

Manfaat dan Hambatan Inovasi

\begin{tabular}{l|l|l}
\hline \multicolumn{1}{c|}{ Inovasi } & \multicolumn{1}{|c|}{ Manfaat } & \multicolumn{1}{c}{ Kendala/hambatan } \\
\hline Koran Anti Ma- & Melindungi pem- & Bahan baku yang digunakan \\
laria & baca dari serangan & dengan tambahan cairan pe- \\
& serangga termasuk & nolak malaria belum ditun- \\
& nyamuk, dengan & jang oleh sistem produksi \\
& bau yang terdapat & yang ada, sehingga menjadi \\
& pada lembaran & kendala saat produksi dalam \\
& koran. & jumlah yang banyak \\
\hline
\end{tabular}

Sumber: Data Lapangan, diolah

\section{Faktor yang Mempengaruhi Inovasi}

Ada beberapa hal yang mempengaruhi proses inovasi yang berlangsung pada Harian Jogja. Diantaranya adalah faktor Organisasi Pembelajaran/ oriented pelanggan, budaya organisasi dan teknis. Ketiga faktor ini memiliki pengaruh besar terhadap inovasi yang telah dijelaskan diatas.

\section{a. Budaya Organisasi}

Harin Jogja dikenal dengan slogan "Berbudaya Membangun Kemandirian" merupakan nilai yang dipegang teguh pada organisasi. Spirit tersebut kemudian di manifestasikan menjadi value yang mendorong setiap komponen pada Harian Jogja untuk bertindak di organisasi. Selain itu, spirit budaya organisasi yang diyakini menjadi alasan penggerak setiap upaya inovasi yang dilakukan di Harian Jogja. Misalnya inovasi yang berlangsung pada konten dan desain Harian Jogja. Kedua inovasi ini lahir dari dorongan value yang dipegang teguh oleh perusahaan.

Adapun budaya organisasi (coorporate culture) yang dimiliki oleh harian Jogja adalah Harmoni, Aktif, Responsibilitas, Jump for Success Dan Obyektif, selanjutnya di singkat menjadi $H A R J O$. Inilah salah satu alasan yang mendorong berbagai inovasi pada harian Jogja. Budaya organisasi tersebut penggerak setiap kerja pada organisasi. Budaya organisasi yang selanjutnya ditanamkan pada setiap awak Harian Jogja baik pada saat reporter maupun pada kegiatan produksi. $^{12}$

Kondisi ini dilakukan atas dorongan dari corporate culture. Reporte harian Jogja harus memegang Harjo dimanapun mereka berada. Misalnya ketika ada kecelakaan yang terjadi, reporter meskipun tidak pada 
jam kerja harus segera membuat liputan yang selanjutnya diteruskan ke bagian admin online harian Jogja untuk diberitakan.

Meskipun demikian, konten dan desain pada inovasi sebagai dorongan dari corporate culture, tetapi Harian Jogja juga masih sangat memegang teguh prinsip-prinsip dan kode etik yang berlaku pada jurnalistik. Sehingga antara corporate culture dengan kode etik jurnalistik tidak saling bertentangan. Misalnya prinsip yang aktif dan responsibility, prinsip ini tidak harus dipahami secara detail bahwa semua informasi harus dilakukan secara aktif dan detail tetapi tetap memperhatikan kaidah-kaidah jurnalistik.

Akhirnya, salah satu point yang ikut berkontribusi terhadap setiap inovasi yang berlangsung pada harian Jogja adalah corporate culture. Sehingga sangat penting bagi perusahaan untuk memiliki corporate culture.

\section{b. Teknis}

Faktor teknis yang dimaksud disini erat kaitannya dengan penggunaan alat (merujuk pada mesin). Inovasi yang berlangsung pada Harian Jogja khususnya pada koran anti nyamuk sangat dipengaruhi oleh faktor teknis. Ketersediaan teknis yang ada di Harian Jogja masih sangat terbatas. Hal ini karena inovasi koran anti nyamuk menggunakan zat tertentu sementara mesin yang tersedia belum sepenuhnya menunjang. Sehingga hal yang juga tidak boleh disampingkan pada inovasi adalah soal kesiapan secara teknis, khususnya pada inovasi yang mengandalkan mesin atau alat produksi seperti yang terjadi pada Harian Jogja.

Selain itu, faktor anggaran juga berkontribusi terhadap proses inovasi pada koran anti nyamuk. Alasannya, cairan yang digunakan untuk terbitan koran anti nyamuk merupakn cairan tertentu dengan harga yang sangat mahal, sehingga berimplikasi pada biaya produksi koran yang efek dominonya pada keadaan keuangan Harian Jogja. Tetapi, bukan berarti bahwa inovasi sepenuhnya harus bergantung pada faktor uang, faktanya ditengah keterbatasan yang ada Harian Jogja masih bisa melakukan inovasi dengan koran anti nyamuk meskipun masih terkendala secara teknis.

\section{c. Organisasi Pembelajaran}

Hasil survey (Lampiran) menunjukan organisasi pembelajaran di Harian Jogja dengan model pengambilan responden secara acak. Hasil survey menunjukkan learning environment composite 71.8 (Median), Learning Processes Composite 57.4 (Bottom Quartile) $\&$ leadership that reinforces learning 75 (Second Quartile).
Data menunjukan bahwaLeadership That Reinforces Learning yang masih tergolong rendah dengan score 75. Keadaan yang tidak menggembirakan ini tidak terlepas dari kepemimpinan pak Anto selaku pemimpin redaksi di Harian Jogja yang masih terbilang sangat mudah, yaitu belum genap satu tahun. ${ }^{13}$ Hasil ini tidak mengejutkan, jika dikombinasikan dengan masa jabatan Pak Anton sebagai pemimpin dalam sebuah oragnisasi.

Sementara, untuk transfer information menempati Top Quartel dengan score 86.7. Ini menunjukan bahwa transfer informasi pada Harian Jogja berlangsung sangat baik. Pada saat penelitian, transfer informasi terekam dengan baik ketika salah satu jurnalistik ataupun crew Harian Jogja yang secara tidak sengaja menemukan kejadian di lapangan, meskipun tidak dalam keadaan dinas, crew dari Harian Jogja masih sempat mengirimkan informasi singkat ke bagian IT yang selanjuutnya di rilis sebagai berita online.

Sehingga dari hasil survei, menunjukan bahwa salah satu faktor yang paling menunjang pada inovasi Haian Jogja dalam kaitannya dengan organisasi pembelajaran terletak pada transfer informasi yang cukup baik. Kekuatan Harian Jogja terletak pada kolektifitas organisasi khususnya pada sharing informasi, sehingga kekuatan ini membentuk crew Harian Jogja menjadi organisasi pembelajaran yang merata disetiap lini baik yang bertugas sebagai reporter maupun yang di bagian teknis dan produksi.

\section{Teknologi Sebagai Pemicu Inovasi Pada Orga- nisasi Bisnis}

Dari hasil temuan di atas, setidaknya tulisan ini sampai pada gagasan sederhana tentang perubahan yang terjadi pada media cetak seperti Harian Jogja sebagai upaya untuk merespon dua dinamika sekaligus. Pertama, inovasi yang berlangsung pada organisasi bisnis sebagai respon terhadap perubahan lingkungan eksternal seperti perkembangan teknologi, yang dalam dimensi organisasi, perubahan teknologi telah membuka peta jalan baru bagi penyesuaian yang mendorong organisasi harus berubah. Peruabahan ini berlangsung mulai dari proses pembuatan regulasi hingga mekanisme kerja yang harus menyesuaikan. Kedua perubahan yang berlangsung dalam skala intenal organisasi berupa perubahan pola kerja.

Dalam banyak kasus, organisasi baik yang berwatak bisnis ataupun yang berkarakter organisasi publik telah banyak bersolek untuk tetap menunjukan eksistensinya ditengah derasnya arus perubahan teknologi yang berlangsung. Kita bisa melihat dari kasus ditempat lain yang telah di sajikan oleh peneliti 
sebelumnya, seperti yang di sajikan oleh Candra (2016), dengan melihat proses inovasi yang berlangsung pada RRI. Sekilas Candra pun mengakui salah satu faktor yang mendorong terjadinya inovasi pada RRI tidak lain karena adanya lingkungan eksternal berupa arus teknologi, yang memaksa organisasi bisnis seperti RRI harus melakukan terobosan. Meskipun, sejauh ini apa yang terjadi pada RRI dengan media cetak Harian Jogja berjarak dalam hal memaknai proses inovasi yang berlangsung. Sampai pada kesamaan faktor pendorong, baik inovasi yang berlangsung pada Harian Jogja maupun pada RRI telah sepakat menjadikan arus teknologi sebagai pemicu terjadinya perubahan pada organisasi bisnis yang pada dampak dominonya akan mendorong proses inovasi. Namun, kedua organisasi bisnis ini telah mengambil jalan yang berbeda dalam membaca arus teknologi. Bagi Harian Jogja, sebagai media yang mengandalkan pasarnya pada "koran cetak" sedikit lebih cemas dengan adnaya perkembangan teknologi. Ketakutan akan, bergesernya selera publik yang padak konteks tertentu akan meninggalkan media cetak menjadi hal yang selalu menghantui Harian Jogja, sehingga dari ketakutan ini dorongan untuk melakukan proses inovasi lebih besar jika dibandingkan dengan apa yang berlangsung pada media lain seperti pada RRI.

Pada aspek yang lain, teknologi memang telah menjadi satu perangkat kerja pada organisasi yang harus diakui, membantu pekerjaan manusia pada organisasi bisnis menjadi lebih efektif dan efisien. Saputri (2011) melalui penelitiannya di sebuah kedai digital di Jogjakarta, telah menunjukan adanya penambahan nilai yang sangat besar setelah digunakannya teknologi untuk pengembangan kedai digital. Saputri, termasuk orang yang kemudian melihat perubahan teknologi dengan cara pandang yang cukup optimisi.

Tetapi, tentu saja ada sisi lain dari arus teknologi yang tidak dilihat oleh Saputri (2011). Bahwa teknologi telah megubah banyak hal termasuk pada penciptaan nilai di organisasi bisnis adalah gagasan yang sepertinya sulit untuk diperdebatkan lagi. Namun, juga tidak mudah menerima teknologi sebagai pola kerja yang baru. Tidak semudah itu menerima serta menerapkan teknologi sebagai bagian dari kerja. Mengubah tatanan kerja pada organisasi bisnis menjadi pra-syarat yang harus dilakukan jika oragnisasi bisnis tersebut ingin menyesuikan dengan perubahan yang ada (Rahman \& Dewantara, 2017 dan Muryani dkk, 2016).

Untuk konteks pada Harian Jogja, perubahan dinamika kerja nampak pada pola kerja organisasi bisnis mulai dari redaksi hingga reporter dilapangan. Per- ubahan pola kerja menyangkut dengan pola koordinasi yang berlangsung pada organisasi Harian Jogja. Teknologi telah mendorong banyak pihak untuk berlomba-lomba menjadi yang tercepat. Dalam hal penyajian berita, Harian Jogja akan menjadi media terdegradasi jika gagal merespon kecenderungan pembaca yang menginginkan informasi tersaji dengan cepat. Bersamaan dengan situasi inilah, pola kerja dalam organisasi bisnis seperti pada Harian Jogja harus mengikuti irama yang berkembang sebagai buah dari adanya arus teknologi.

Lebih spesifik, perubahan pola kerja yang berlangsung pada Harian Jogja nampak pada relasi kerja yang lebih luwes. Setiap berita yang akan di rilis kadang ditentukan tanpa harus melakukan pertemuan terlebih dahulu. Ruang-ruang komunikasi pada organisasi Harian Jogja bertransformasi dari ruang rapat ke ruang virtual, dengan mengandalkan teknologi seperti groupgroup WA.

Perubahan pola kerja sebagai akibat dari arus teknologi bukan kali pertama berlangsung pada Harian Jogja, oleh Kriska (2013) misalnya telah jauh melihat dampak arus teknologi yang telah mendorong proses inovasi pada surat kabar. Namun, Kriska hanya berhenti pada soal distribusi berita yang lebih menyasar kelompokkelompok petani. Sehingga gagal memotret, proses inovasi yang lebih pada hubungan kerja pada organisasi bisnis. Namun, sejauh ini Kriska telah berkontribusi besar pada studi ini khususnya untuk menunjukan peta geopolitik pembaca media cetak yang kemudian mengalami kesenjangan cukup tinggi antara daerah perkotaan dengan daerah pedesaan. Selain karena, minta baca yang berbeda ada korelasi tentang kepemilikan smartphone yang lebih cenderung membuat sebagian masyarakat perkotaan mulai beralih pada berita-berita yang tersaji secara online. Keberadaan smartphone tersebut yang sekali lagi juga turut andil besar terhadap perubahan pola kerja yang berlangsung pada oragnisasi bisnis.

\section{KESIMPULAN}

Saat ini teknologi tidak hanya mempermudah pekerjaan manusia menjadi lebih efektif dan efisien, namun keberadaan teknologi telah menjadi ancaman bagi sektor kehidupan yang lain. Salah satunya mengancam eksistensi koran cetak. Keberadaan teknologi menjadi momok yang sangat menakutkan bagi keberlangsungan bisnis koran cetak. Alih-alih mempermudah kerja peliputan, keberadaan teknologi justru menghambat laju penjualan bagi koran cetak.

Keberadaannya teknologi ditengah-tengah masyarakat menggilas selera akan koran cetak yang mulai 
tereduksi oleh selera yang lebih digital. Penyampaian informasi secara instans dan cepat menjadi ciri khas dari kemajuan teknologi di masa kini. Hal ini pula yang kemudian menjadi ancaman yang cukup serius bagi keberlangsungan media cetak di masa yang akan datang.

Namun, ketakutan akan gempuran teknologi tidak membuat gentar Harian Jogja sebagai media cetak. Dengan gempuran teknologi yang datang di segala lini membuat Harian Jogja terpaksa melakukan inovasi sebagai bentuk penyesuain pasar atas perubahan dan dinamika yang terjadi seperti perubahaan seleran atas rongrongan teknologi. Alhasil dengan semangat yang terus terbakar, eksistensi Harian Jogja masih tetap konsisten sebagai media cetak lokal yang mampu bertahan ditengah hadangan teknologi. Eksistensi ini tentu saja lahir dari satu tindakan berani melampui kenormalan yang selama ini terkungkung pada Harian Jogja. Hasilnya cukup mengejutkan, dengan melakukan berbagai uji coba inovasi seperti memperbaharui desain, membuat koran anti malaria dan menyuguhkan konten berita yang lebih khas pada ekonomi dan bisnis. Harian Jogja masih bisa bertahan menghadapi gempuran teknologi saat ini.

Keberhasilan ini tidak terlepas dari budaya organisasi yang terus dikembangkan oleh Harian Jogja. Dengan mengusung slogan berbudaya membangun kemandirian, menunjukan sebuah sikap yang saling teguh dalam menegakkan value lokal sebagai norma yang secara konsisten menggerakan segenap crew dan reporter pada Harian Jogja untuk terus bergerak dan berinovasi.

Selain itu, distribusi pengetahuan yang merata di segala lini menjadi ciri khas yang terjadi pada Harian Jogja. Dimana pada keadaan ini menunjukan Harian Jogja sebagai organisasi pembelajaran yang menekankan kebersamaan dan kekeluargaan sebagai acuan utama dalam menjalakan aktifitas. Yang nilai ini secara positif dikonversi sebagai ikatan kekeluargaan menyampingkan relasi kerja, sehingga proses pertukaran gagasan menjadi lebih cair. Akhirnya ide-ide inovasi begitu fresh dengan suasan yang sangat akrab.

\section{Daftar Pustaka}

Birkinshaw, Julian, Bouquet, Cyril, Barsoux. J-L. 2011. The 5 Myths of Innovation. Sloan Management Review. Rev 52. No. 2 Wint 2011 p. 43-50.

Candra, Anisa Cita. 2016. Studi Komparasi Proses Inovasi (Proses Inovasi RRI Yogyakarta dan Radio Swaragama). Skripsi. Universitas Gadjah Mada. Tidak Diterbitkan

David. S Pottruck. 2002. Editor Hesselbein, dkk. 2001. Leading for Innovation and Organizing for Results (Chapter 10, How company culture encourages innovation. HGS: 119-128). JosseyBass books. San Francisco

Dyer. Jeffrey H. dkk. 2009. The Innovator's Dna. Harvard Business Review Notice of Use Restrictions.

Garvin, David A. Edmondson, Amy C. and Gino, Francesca. (2008). Is Yours a Learning Organization? Harvard Business Review.

Jaskyte, Kristina. 2011. Predictor of Administrative and Technological Innovations in Nonprofit Organizations. Public Administration Review.

Kanter, Rosabet Moss.2002. Leading for Innovation and Organizing for Results (Chapter. Creating theEnvironment That Encourages Innovation)Editor.Hesselbein, Jossey-Bass books. San Francisco

Kriska, Mesalin. 2013. Kontribusi Surat Kabar Local DIY Dalam Penyebaran Informasi Inovasi Pertanian. — Universitas Gadjah Mada. Tidak diterbitkan

Muryani, dkk. 2016. Pengaruh Pengalaman Kerja, Pengawasan Kerja dan Spesialisasi Kerja Terhadap Pemahaman Beban Kerja Dengan Pemanfaatan Teknologi Informasi Sebagai Variabel Intervening. Journal Of Management. Vol. 2. No. 2 Maret 2016.

Rahman. Abdul, Dewantara. Rizki Yudhi. 2017. Pengaruh Kemudahan Pengunaan dan Kemanfataan Teknologi Informasi Terhadap Minat Menggunakan Situs Jual Beli Online. Jurnal Administrasi Bisnis. Vol. 52, No. 1 November, 2017.

Salge, Torsyen Olier \& Vera, Antonio .2012. Benefit Ting from Public Sector Innovatio: The Moderating Role of Customer and Learning Orientation. Public Administration Review. Vol. 72, Iss. 4 , pp. 550-560. 
Saputri, marheni eka. 2011. Analisis Inovasi Nilai di Kedai Digital Yogyakarta. Thesis. Universitas Gadjah Mada. Tidak diterbitkan.

Vigoda, Eran, Gadot, dkk. 2005. Public Sector Innovation for The Managerial and The Post- Managerial Era: Promisesa and Realities A Globalizing Public Administration.International Public Management Journal. 8 (1). 2005. p. 57-81.

Yulianarko, rangga. 2013. Respon Petani Terhadap Berita Inovasi Pertanian Pada Media Televise di Kecamatan Kalasan Kabupaten Sleman. —— Tesis. Universitas Gadjah Mada. Tidak diterbitkan.

Website

http://www.nielsen.com/id/en/press-room/2014/ nielsen-konsumsi-media-lebih tinggi-di-luarjawa.html, Diakses pada Kamis, 8 Juni 2016. Pukul 12.44 di Ruang Penerbitan berkala Perpus UGM LT.1

Dokumen-Dokumen

Profil Harian Jogja

Wawancara

\section{Catatan Akhir:}

${ }^{1}$ Wawancara dengan pimpinan redaksi, Pada 29 Mei 2016, diaula kantor redaksi Harian Jogja.

${ }^{2}$ Wawancara dengan pimpinan redaksi, Pada 29 Mei 2016, di Aula kantor redaksi Harian Jogja.

${ }^{3}$ Hasil wawancara dengan Pak Anton di Kantor Redaksi Harian Jogja, pada 7 Juni 2016.

${ }^{4}$ Wawancara dengan Pimpinan Redaksi Harian Jogja, pada Rabu, 22 Juni 2016.

${ }^{5}$ Hasil wawancara dengan Pimpinan Redaksi Harian Jogja 2222 Juni 2016.

${ }^{6}$ Wawancara dengan pimpinan redaksi, Pada 7 Juni 2016, di aula kantor redaksi Harian Jogja. Pukul 15.30 WIB.

${ }^{7}$ Wawancara dengan pimpinan redaksi, Pada 7 Juni 2016, di aula kantor redaksi Harian Jogja.

${ }^{8}$ Wawancara dengan pimpinan redaksi, Pada 7 Juni 2016, di aula kantor redaksi Harian Jogja. Pukul 15.30 WIB

${ }^{9}$ Wawancara dengan pimpinan redaksi, pada Selasa, 7 Juni 2016.

${ }^{10}$ Wawancara dengan pimpinan redaksi, Pada 7 Juni 2016, di aula kantor redaksi Harian Jogja. Pukul 15.30 WIB

${ }^{11}$ Wawancara Pak Anto, Pukul 20.30 WIB di ruang kerjanya (Rabu, 22 Juni 2016)

${ }^{12}$ Wawancara Selasa, 7 Juni 2016 di ruang rapat Harian Jogja.

${ }^{13}$ Wawancara dengan Pimpinan Redaksi Harian Jogja, pada Rabu, 22 Juni 2016. 